\title{
English Pibid and the Big Screen: Expanding Pre-Service Teacher Education Spaces
}

\section{PIBID Inglês e a telona: ampliando espaços formativos}

Ana Karina de Oliveira Nascimento*

*Universidade Federal de Sergipe (UFS), Aracaju, Sergipe / Brasil akcoliveira@gmail.com

https://orcid.org/0000-0002-3014-0659

Ana Lúcia Simões Borges Fonseca**

**Universidade Federal de Sergipe (UFS), Aracaju, Sergipe / Brasil

analucia.sbf@gmail.com

https://orcid.org/0000-0003-4285-7064

\begin{abstract}
Teacher education can take place in multiple spaces besides the school environment (university and basic education schools), following different paths and in a decolonial way. Having this in mind, a qualitative research with an interpretative scope was conducted during a year and a half, on the range of the English project of the National Pre-service Brazilian Teacher Education Program (Pibid) at a federal university in Brazil. In this article, the focus is on the analysis of pre-service teachers' field diaries and their content concerning one of the activities developed as part of the project: going to the movies and reflecting upon some films. The experience revealed how pre-service teachers had the chance to reflect on the relationships they were able to establish with teacher education, and the readings and experiences provided by Pibid, thus corroborating the importance of decolonizing practices.
\end{abstract}

KEYWORDS: Teacher education; Pibid; English language; decolonial practices; movies.

RESUMO: A formação de professores pode ocorrer em vários espaços além do ambiente escolar (universidade e escolas de educação básica), seguindo caminhos diferentes e de maneira decolonial. Nesse sentido, foi realizada uma pesquisa qualitativa, com escopo interpretativo, durante um ano e meio, no âmbito do projeto de inglês do Programa Institucional de Bolsa de Iniciação à Docência (Pibid), em uma universidade federal brasileira. Neste artigo, o foco está na análise dos diários de campo dos professores em formação inicial e seu conteúdo referente a uma das atividades desenvolvidas como parte do projeto: 
ida ao cinema e reflexão sobre alguns filmes. A experiência revelou como os professores em formação inicial tiveram a chance de refletir sobre as relações que estabeleceram entre a formação de professores e leituras e experiências proporcionadas pelo Pibid, corroborando a importância de práticas decoloniais.

PALAVRAS-CHAVE: Formação de professores; Pibid; língua inglesa; práticas decoloniais; filmes.

\section{Introdução}

The National Pre-service Teacher Education Program (Pibid) began at the end of $2007^{1}$ in Brazil, being the first call for the program launched by the Coordination for the Improvement of Higher Education Personnel (CAPES) in early 2008. However, only one year later, in 2009, the program started to cover the area of foreign languages, which included the English language. Since then, the Federal University of Sergipe (UFS) has presented the English subproject as part of its institutional project and has been given scholarships for this area, the subject of which we will focus on in this article. $^{2}$

One of the first objectives of Pibid was: "to promote students from federal institutions of higher education first teaching practices and to prepare pre-service education at a higher level, in undergraduate courses, to work in public basic education" (BRASIL, 2007, n. p.). In order to do so, the partnership between professors from higher education institutions (HEI), called area coordinators (AC), and teachers from basic education working in public schools, called supervisors (S), is crucial to the materialization of the program. Both of them work together in order to allow undergraduates,

\footnotetext{
${ }^{1}$ See: Normative Ordinance n. 38/MEC, Dec. 12, 2007 (BRASIL, 2007).

2 The reason for the late insertion of the foreign language area in the program refers to the fact that this field of study was not considered a priority when the ordinance that regulated Pibid was launched, and, consequently, the launch of the first public notice of the program. According to the text of the normative ordinance n. 38/MEC/2007, Pibid should "give priority to prepare teachers to work in the following areas of knowledge and teaching levels, in that order: I - for high school: a) degree in physics; b) degree in chemistry; c) degree in mathematics; d) degree in biology; II - for high school and for the final years of elementary school: a) science degree; b) degree in mathematics; II - in a complementary way: a) degree in the Portuguese language; b) degree in musical and artistic education; and c) other degrees." (BRASIL, 2007, n. p.).
} 
pre-service teachers (PST), who are either scholarship holders or volunteers, to participate in a broad process of learning to become a teacher.

The foreign language area of English at UFS has been an integral part of Pibid, uninterruptedly, since 2009, when the first call for proposals covered this specific area. Considering the 2018 call for proposals, in particular, which is the heart of this article, it was possible to form two groups of English, which included the participation of $02 \mathrm{AC}, 06 \mathrm{~S}$ and 60 PST, with 48 scholarship holders and 12 volunteers. Hence, 68 participants composed the group.

In what regards the 2018 call mentioned before, the AC, authors of this article, had to fill in, on the Freire Platform ${ }^{3}$ (in order to meet CAPES requirements), several items that would somehow be in agreement with the actions of the English subproject. Because we understand teacher education as a set of actions that go beyond the physical space of the classroom, we planned the following activities to be developed: meeting arrangements, study groups, workshops, competitions and knowledge olympics. Such actions were part of the group of activities offered at the Freire Platform, therefore, designed by CAPES and already made available to AC. However, as we considered the list was insufficient concerning what we wanted to develop and accomplish, we added the following tasks to the item "Other" activities, which were also present on the Platform: I) Participation while visiting schools; II) Survey of local characteristics, previous knowledge and needs of teachers and students from schools participating in the project (in loco research, reading of school documents etc.); III) Implementation of projects built collectively in participating schools.

We opted to place these items in "Other" activities because we considered the register of the research work about teacher education to be of the uttermost importance for the development of Pibid. In the current project, such a registration occurred when the whole group visited the participating schools, by means of the elaboration of different data collection

\footnotetext{
${ }^{3}$ The Freire Platform is a system developed by the Ministry of Education (MEC) that has dealt with the provision of courses for teachers. In the case of this article, it was used by Pibid to record activities related to the program. To know more about the system, visit the following website: https://sso.capes.gov.br/sso/oauth?response_ type=token\&redirect_uri=https://eb.capes.gov.br/auth\&realm=2\&client_id=freire.capes. gov.br\&scope $=\&$ state $=$ capes_oauth. Last access: Nov. 23, 2019.
} 
instruments based on local characteristics and on previous knowledge and the needs of teachers and students of the schools participating in the project (in loco research, reading school documents etc.). This phase was followed by analysis and discussion of the data collected so that the next phase would be the implementation of the pedagogical projects to be (re)built.

In addition to the activities previously mentioned, by following the order of disposition of the activities on the Freire Platform, we added the following events: meetings of the group and presentations in an event abroad. This last item was added in the hope of having the chance to socialize our work abroad, in case there had been financial resources to do so, which, in fact, did not come to fruition. However, it is on the activity of our group meetings that we want to focus in this text, in view of the rich nature of the meetings involving AC, S and PST throughout this edition of Pibid.

Therefore, our aim is to share the experiences we had during the English subproject of Pibid, which reinforced our understanding about diverse local teaching spaces and the ones we brought up and worked with during the meetings of our group. Thus, despite the various activities we developed through the meetings, which took place during the whole period of the project, our attention in this text lies on a particular aspect: activities developed at the movies.

\section{Methodological Path}

Having a broader understanding of what teacher education means, we conducted the English Pibid project not only as a teacher education program that traditionally teaches students to perform the job in the classroom as teachers, but also as a space for questioning and reflecting upon our teaching job. Thus, pre-service teachers and S, together with AC, were encouraged to become researchers of their own practices and experiences. They were also required to register all the activities they were involved in, by playing different roles, as part of the program together with their impressions in field diaries, throughout the duration of the program, which lasted one year and six months.

Some of the activities carried out beyond the classroom space as part of our English Pibid meetings involved: experiences at school and registers of impressions in field diaries of each one of the PST, in which they shared their reflections. Such reflections were related to the meetings; reading and 
discussion of theoretical texts by establishing relationships with their school experiences; reflections on the teaching profession, the place of the English language in our society, life in society as a whole, through films. Besides that, we participated in a Public Hearing in the Legislative Assembly of the State of Sergipe in order to contribute to thinking about the relevance and continuity of programs such as Pibid; direct actions in the process of purchasing materials to enable the carrying out of pedagogical activities at school, which implies knowing processes related to the use of public funds and their requirements, amongst other issues.

In this article, particularly, we will deal with one of the activities developed during the meetings of our English group, namely: going to the movies. We chose to focus on this activity, rather than on the others, due to space limits and because we understand that it was a teacher education activity developed outside the school environment (university and basic education school) and by means of which the local knowledge and contexts were the core of the problem present in teacher education.

This article falls within the scope of languages, more specifically, applied linguistics (AL). According to Moita Lopes (2006, p. 22): "politicizing the act of researching and thinking about alternatives to social life are an intrinsic part of the new ways of theorizing and making applied linguistics". Within the sphere of AL, it is an article resulting from qualitative research of an interpretative nature that had the field diaries of pre-service teachers and supervisors as tools for data generation and analysis, accessible by the authors of this text. In the diaries, the participants freely registered their impressions about their going to Cine Vitória (a local movie theater) experience. Initially, they registered their impressions on having watched the film "Abraço" and having participated in the discussion about it. Then, they also registered impressions on having watched the film "Bacurau" and having taken part in the discussion about the film, seeking to mention the relationships they established between being a pre-service English teacher with their readings throughout Pibid, in an attempt to establish connections with their teacher education experience. This process of writing in their field diaries took a year and a half, which represents the entire time Pibid was carried out at the Federal University of Sergipe. However, due to our scope of analysis, only the registers related to the activities connected to the film-watching experiences are considered throughout the analysis presented in this article. 


\section{Questioning truths in the education of English teachers}

As some authors have discussed in the field of AL, the inheritances of colonial relations have been present in research, teaching practices and teacher education (JUCÁ, 2016; PESSOA; HOELZLE, 2017), especially in the area of foreign languages, and, to be more precise, in the English language.

According to Jucá (2016), the modernist movement, of which we are the result and by which we are still influenced - in the name of progress and

inspired by values such as universalism (the existence of universal truths), standardization (homogeneity, uniformity and inflexibility) and sistematicity, $[\ldots]$ aimed, above all, at predictability, efficiency and progress, and thus considered diversity, variability, contingency and differences problematic. The objective was, above all, a uniform march towards progress. [...] (JUCÁ, 2016, p. 238, translated by the authors). ${ }^{4}$

In addition, it is through colonialism, in turn, that ideas related to modernity and the achievement of progress are disseminated, especially in the cultures of colonized peoples. According to Mignolo (2012, p. ix), "for five hundred years, universal history was told from the perspective of a local history, that of Western civilization, an aberration, indeed, that passed for the truth".

As Maldonado-Torres (2007) points out, however, colonialism precedes coloniality, which survives colonialism. Coloniality is related to the

logic of domination and exploitation, explains how different spheres of human life - including land grabbing, the exploitation of work, the control of gender and sexuality, knowledge and subjectivity, amongst others - would be interrelated and integrated. Following such logic, the invasion would be justified by the promises of modernity, development and democracy; such justification would hide, however, the dismantling of local forms of socioeconomic organization, knowledge and subjectivity, thus establishing the hegemony of eurocentric values, beliefs and truths [...]. Thus, in the name of civilization, the modernist enterprise resulted [...] in a kind

\footnotetext{
${ }^{4}$ All citations translated from Portuguese to English are the authors' responsibility.
} 
of erasure of the local knowledge of the colonized peoples (JUCÁ, 2016, p. 241, translated by the authors).

Understood as the darker side of modernity (MIGNOLO, 2012), coloniality "survives colonialism. It is maintained alive in books, in the criteria for academic performance, in cultural patterns, in common sense, in the self-image of peoples, in aspirations of self, and so many other aspects of our modern experience" (MALDONADO-TORRES, 2007, p. 243).

Hence, we experience the continuity of traits of colonial relations in the contemporary times, including teacher education. For Kumaravadivelu (2014), it is necessary, especially in the area of teacher education and, mainly, in the English area, that we act in a decolonial perspective. For the author, decolonial practices need to be thought and put into practice by local actors, sensitive to their contexts and must involve:

Restructuring the existing teacher education programs so that prospective teachers are helped to develop the knowledge, skill, and disposition necessary to become producers, not just consumers, of pedagogic knowledge and pedagogic materials. [...] This also involves developing the capacity in them to systematically monitor their own teaching acts in order to ensure continuous professional self-development (KUMARAVADIVELU, 2014, p. 16-17).

By taking these questions and theoretical matrices into consideration, we proposed the going to the cinema experience, during the activity entitled "meetings of the group". It is about two of these moments that we will look at in the section that follows, aiming to analyze how the development of these experiences, which took place in a space other than the school, contributed to the education of the teachers involved: in-service teachers (supervisors) and pre-service teachers (undergraduate students) through the analysis of their field diaries.

\section{From the university to the movies: educational paths on the big screen}

As coordinators of the English area, one of our proposals was to purchase tickets for cultural activities involving the undergraduate students, making use of the Pibid funding. In particular, we thought of going to the movies so that students could reflect, through the films, on the relationships 
they were able to establish with teacher education, with the role of English and with the readings and experiences provided by Pibid.

Our first decision was regarding the choice of the movie theater. We decided, taking into account a political attitude, to seek partnership with Cine Vitória, which represents, in the context of the city where the project took place, an alternative movie theater to the American movie theater chain located in the two shopping malls in our city. Thus, we would be reflecting decolonial choices, that is, ways of thinking and being in the world with an eye to changing the perceived universality of the knowledge and culture produced in the Global North (SOUSA SANTOS, 2007).

After choosing the place, we proceeded to the choice of the films to be watched by Pibid participants: area coordinators, supervisors and preservice teachers. Our selections also reflected our theoretical guidance, since we would like to promote a discussion that took into account the teaching career, more specifically that of the context of Sergipe, being, therefore, a choice motivated by our experiences. In this respect, the film "Abraço" was chosen since we understood it would be a fruitful option. The film tells the story of the moment in which:

Teachers from Sergipe decide to join forces to fight for their labor rights. Together, they establish a confrontation against the State Government of Sergipe to ensure that their career achievements would not be disregarded. On a long trip to Aracaju, the group of teachers tries to convince the members of the Court of Justice not to disregard the teachers' positions. Amid all this movement, Ana Rosa (Giuliana Maria) represents the difficulties faced by a mother, married to a man who does not understand her, besides having the disapproval of her mother, who shows herself to be a sexist and conservative person (ADORO CINEMA, 2019, n. p.). ${ }^{5}$

It is a film produced by the Union of Workers in Education of the State of Sergipe, released in the national circuit only in 2020, which portrays an important struggle by the teachers in Sergipe, in 2008, for the guarantee of acquired labor rights, so that their careers would not suffer significant losses. It is a documentary featuring renowned personalities from the

5 Available at: http://www.adorocinema.com/filmes/filme-275402/. Last access: Dec. 3, 2019. 
teaching staff, as well as ordinary teachers who participated in that historic moment of struggles and conquests. Parallel to this larger struggle, the film portrays the story of other teachers, like Ana Rosa, representing several teachers in that context, and the problems involving their relationships beyond the teaching career, but which are very much connected to the colonial power matrix (GROSFOGUEL, 2010). In particular, it focuses on issues related to the exercise of exploitation and domination in the gender dimension: the privilege of men over women.

On gender issues, we highlight the perceptions of some pre-service teachers, which were registered in their field diaries:

Luiz: ${ }^{6}$ The fact of witnessing events such as husbands who do not support their wives who are teachers and even abandon them, as well as governments that attack teachers, made me think about questions such as: how could a family be against a profession that is increasingly seen as essential by society, and is harshly attacked by members of the government?

Vera: [...] the emphasis given by the film to women because they form a majority when it comes to literacy and elementary education, as well as in the teaching contingent as a whole. So, it is a category of mass, but not mass based on the sociological concept in which individuals are homogeneous and moldable like a piece of clay (the famous maneuver masses), far from it, our category would not fit the moldable label; we shout diversity.

Maria: Besides not showing only what happened, it [the film] also shows some more details of the main character's personal life, what things are like in her house, and a relevant part, [...] when her mother calls her "Revolutionary", something like that, and she starts laughing and thanking her mother for the compliment; basically she doesn't have to be "the housewife", she can also be a teacher who loves and fights for education.

When the pre-service teachers wrote about their impressions on the film "Abraço", in their diaries, and about the relationships they

\footnotetext{
${ }^{6}$ In all references to pre-service teachers, we use pseudonyms, in order to preserve their identities. Concerning the diaries, it is important to highlight that they were originally written in Portuguese and then translated to English, with due alterations related to the language used by the PST.
} 
established of being an English teacher with readings made throughout Pibid, they mentioned several issues, besides the one about gender. They also highlighted: the importance of knowing the struggles of teachers, the context of teaching in Sergipe and the problem involved in that historical moment in which many of the undergraduate students had been students in the public education system. In particular, we emphasized the issue of knowing the local context beyond the more formal and global spaces of teacher education, as pointed out by Kumaravadivelu (2014). In relation to this, we bring the testimony of Samoa as it was recorded in her field diary:

Samoa: On October 31, we went to Cine Vitória with Pibid, for the first time, to watch the movie Abraço. To many of the participants it was their first time in that movie theater, which is located downtown and is part of the local culture and tourism. I think it is important to emphasize here that this meeting held in the cinema only highlights the importance of the program in the education of students, as its impact goes beyond the walls of the university, providing those who are part of it with an extremely significant cultural experience, connecting not only the inhabitants of the city with local culture, but also those born in neighboring cities, who had the opportunity to get to know a little of their history and culture for the first time. In this respect, the English Pibid demonstrates once again its commitment to form not only teachers, but citizens who recognize the world and see themselves in it.

Another register that appealed to us was that of a pre-service teacher who, in addition to recognizing that part of the recording of the film had taken place in the public school where he had been a student, pointed out that back then as a school boy, he was unaware of the teachers' struggle and understood the strike as a class delay mechanism. In his words:

Thor: In many scenes I was very excited because some of them had been recorded at $[. .$.$] the school where I did my$ elementary and high school courses. My memories took me back to when I was a student at the time of these struggles. And I speak on behalf of all my classmates at that time that we only knew that the teachers were on strike, but they never told us the reason, such information did not reach us. The information we had knowledge of the most was that of the scenes in the film that showed the media slandering and 
belittling the teachers' struggle [...]. This scene deeply moved me because our struggles are mostly muffled and diminished by the media. In spite of all the difficulties we have to go through, we still have a big enemy like the media.

Thor's testimony points to the need for teachers to talk with students in order to give them the chance to know other narratives about what happens in the space of the teaching struggle, besides the one that is conveyed by the mainstream media. It is worth mentioning that this observation made by the pre-service teacher was possible, because it was provided by the opportunity to watch the film and, particularly, because he was given the chance to discuss and reflect about it. Another PST, Violeta, reinforces teachers' educational role, which goes much beyond their discipline, corroborating Thor's ideas. She also highlights the role of Pibid in the context of teacher education, when she writes:

Violeta: The film brought us closer to a cause that is also ours, as prospective teachers, making us, as participants of Pibid English project, realize what we had already discussed in other meetings, that the role of education is not restricted to the classroom and that we are participants in social works that demand and need a 'yes' from everyone so that the task of cultivating education can be achieved.

Thus, the production of the film invites us to embrace our profession as well, since only by trying to defend education will we succeed. The learning resulting from this experience connected us to the reality of the profession. The scenario of the State of Sergipe touched us even more, since the fight is here and now, and the fact that we debated the film at the end enriched the experience even more. Through the debate with the representative of the State Basic Education Workers Union (named SINTESE) ${ }^{7}$ we had the opportunity to clarify our questions and to talk a little more about the details pertinent to Pibid.

Regarding the debate mentioned by Violeta, we highlight two passages extracted from other PST's field diaries that we considered to be relevant:

\footnotetext{
${ }^{7}$ To know more about the Union, see: https://www.sintese.org.br/. Access: November 13, 2019.
} 
Lara: After the film, we had a debate with the former president of the union [...]; it was he who was in charge of all the movement and who represented the teachers in the House of Representatives. Talking to him, we were able to ask questions about the film and how things went at that time; with the debate I discovered that this was one of the biggest movements with teachers that SINTESE managed to do.

Silvânia: After the film, we had the presence of $[. .$.$] the$ president of SINTESE at the time, who told us about the backstage of the film, the production process and went a little deeper into the episode reported in the film, in addition to answering some questions from those present. Particularly, I thought this proposal of the coordinators for our meeting was great, because it allowed us to watch a local film, about an episode that I believe is important to know, since, as preservice teachers, we need to be aware of what this profession involves, especially in the space where we live. In addition, I believe it is quite enriching and beneficial to have this cultural moment and also to value the local movie theater, both the film in question and the space of Cine Vitória, given the difficulty of these independent movie theaters to survive.

The testimonies we have shown highlight the relevance of the debate promoted with the participation of a guest, an important part of the struggle portrayed. His participation, together with the fact that the educational space took place in an alternative context, was highlighted by Silvânia - a pre-service teacher, for whom these other spaces need to be occupied. Once again, we return to the conceptions of the colonial power matrix (GROSFOGUEL, 2010) to emphasize that one of the dimensions of coloniality, in the exercise of exploitation and domination, is the economic dimension, which tends to value the center in relation to the periphery - in this case, American global cinema to the detriment of local cinema. And that was one of the questions that we wanted to discuss with the students.

The second film we watched was "Bacurau". It is a Brazilian production of 2019 that tells the following story:

Shortly after the death of Dona Carmelita, at the age of 94, the residents of a small village located in the Brazilian hinterland, called Bacurau, discover that the community is no longer on any map. Gradually, they notice something strange in the 
region: while drones are flying through the sky, foreigners arrive in the city for the first time. When cars become victims of gunshots and corpses begin to appear, Teresa (Bárbara Colen), Domingas (Sônia Braga), Acácio (Thomas Aquino), Plínio (Wilson Rabelo), Lunga (Silvero Pereira) and other inhabitants come to the conclusion that they are being attacked. It remains to identify the enemy and collectively create a means of defense (ADORO CINEMA, 2019, n. p.). ${ }^{8}$

Again, the pre-service teachers were invited to participate in one of the English meetings at Cine Vitória, where everyone was able to watch the aforementioned film and discuss it right away, a moment in which we counted on the presence of a professor from our federal university, bachelor of Arts with a specialization in cinema, for the debate. Different comments were recorded in the field diaries of the PST, amongst which we start by highlighting those that connect with the colonial power matrix in the ethnic-racial dimension, as discussed by Grosfoguel (2010). According to the author's ideas, peoples of the global north are understood as being superior, thus presenting themselves in a privileged position. In the case of this film, that would be so to the detriment of the Brazilian people or even to our ability to produce good films, as the statements below highlight:

Maria: I think that because it is a "Brazilian" film, I did not expect it to be as well produced or to have a plot as unexpected as it was.

Thor: The film demonstrates the danger of all this idolatry for foreigners, all of this: "gringo said, we lie down, roll and swing our tails" ... The film shows the naked truth that many Brazilians do not understand: even if you have fair skin, you are not white, you are Latin American. And even if in the place where you were born you had European colonies, it does not make any difference as it is shown in the scene of the southerners wanting to bond with the Americans.

Samoa: I believe that the thing that moved me the most about the film is that it clearly brings the idea of the struggle of a people excluded by a system that murders the poor, the black,

\footnotetext{
${ }^{8}$ Available at: http://www.adorocinema.com/filmes/filme-247818/. Last access: Sept. 1, 2019.
} 
the women, the LGBT people, in a cold and sadistic way. It rekindles the struggle of the Northeastern people who always had to shout to be seen, and if necessary, even if under the influence of a psychotropic, revive the cangaço and defend their territory and their people. Again, it is a film that carries a very strong notion of identity, an identity that needs to be reaffirmed in order not to be taken, mainly by the North American and Eurocentric white supremacy.

In this context, it is necessary to retake the colonial, military and religious heritage in Brazil. After all, as it is pointed out by Pardo (2019, p. 203), what we can observe today in our country is that:

even after the independence of Brazil, the colonial presence remains one way or another, either to the economic dependence of more 'developed' nations, or by the importation of sociocultural standards considered to be of greater prestige, at first, the European, and more recently, the American.

As the readings of the pre-service teachers reveal, these legacies, part of the ethnic-racial dimension, besides being strong, expand in the relations that derive from it, spreading amongst the southern Brazilians (of predominantly white and European origin) in opposition to the ones from the Brazilian Northeast. The following excerpts from the pre-service teachers' diaries discuss this issue:

Luiz: it is a positive film, which brings reflections on both the overvaluation of North Americans and the political aspects regarding the reckless care that poorer populations receive. Another striking factor that caught my attention in the film was: the characters of the south of Brazil, who, in general, thought to be "white" and superior to the people of the Northeast, which is still a reality today.

Leise: the presence of tourists represents the new, the different, the characters that represent the "developed" part, considering that after a certain point in the film the same tourists who pass through the city, who initially present a falsely friendly aspect, amid the conversation with foreigners who yearn to kill, reveal that they are not the same as the residents of Bacurau, as they are "white", and justify such a fallacy about the idea that they came from the southeast of the country and descended 
from Italians and Germans; such a saying "falls apart", when they are reminded that they are only Latinos, and that like the residents of Bacurau, they are considered part of the same denomination.

Perhaps because they are located in the northeast of Brazil, where they are part of Pibid, and also driven by the provocations that we sought to promote in the English subproject, many of the pre-service teachers recorded, in their diaries, their identification and notion of belonging in relation to the film. Especially in a context of English teacher education, considered a prestigious language, we understand that discussing asymmetric power relations is essential and leads pre-service teachers to reflect on their place of speech and to exercise reading the world while reading themselves (MENEZES DE SOUZA, 2011):

Myrtes: Seeing the elements of Cangaco present in it [in the film] and knowing how acclaimed it has been, made me feel even prouder of the Northeast and of our history.

Josimara: I made a note in my notebook: "I am from there", for some reason at that time I did it. The film was being played and, at the same time, a film was being played in my head, a film about the reality of the hinterland where I came from, the abandonment of the State, and that was the part that shocked me the most, when, at last, the direct connection between the State and its interest in killing the people, history, dignity, humanity and the physical place of that city is made clear. I thought to myself that the State does all of it with peoples, whatever they may be, when they are absent and allow these people to be put apart, in misery, in order to omit their role in offering education, health, work, leisure and everything else that people need to be a citizen [...]. In the discussion it can be said that we can see humanity in the people of Bacurau; even behind all the violence portrayed in the film, we see people who resist for their lives without losing hope, and do not become like their enemy. To be a teacher who loves what he does is to be like the people of Bacurau; to never give up and be, above all, a strong person!

Another issue in the film, according to the view of the pre-service teachers, is what we consider as an unfolding of the ethnic-racial dimension, that is, the linguistic dimension of the colonial power matrix, according 
to Grosfoguel (2010). The linguistic dimension in this case relates to the privilege of European languages or, as Pardo (2019) points out, of the American language - referring to the English language spoken by people born in the United States, which is said to be superior to others. In the case of the film, the invaders, who are superior, speak English, the dominator's language. The pre-service teachers, in turn, exercised reflection on this issue by relating what they saw in the film with activities developed throughout Pibid or within their teaching practices:

Vera: I was thinking about references of other cinematographic works and the role of English in such productions. It was not Italian, Mandarin or Hebrew that the antagonists spoke, it was English, and this was an implication that I found interesting to think about. Sadists, crazy to have fun with blood, they reflect a stereotype of American culture that they always want to dominate. So I made a bridge with the film "Schooling the World" in which it is clear that English is the language of domination and success - or at least that is what we were led to think about.

Thor: The relation I make with teaching is that due to the fact that I am an undergraduate student of English, society expects me to be a person who loves everything that comes from the United States. An image that I always insist on breaking in my social life. While teaching, it is important to remember language teaching as a means of building citizenship, which means enabling students to reflect critically on their position in society and making them learn the language not only with this neoliberal view of the labor market and of travelling to the USA or Europe, but for them to learn the language to transform themselves and the society around them.

We understand that reflections such as those presented by the preservice teachers are related to what Kumaravadivelu (2014) discusses, that is, issues of power and hegemony present in the teaching of English, which are established in order to reinforce the maintenance of subordinates in situations of subordination. According to the author, "In the educational

\footnotetext{
${ }^{9} \mathrm{It}$ is a film also watched and discussed in the English subproject of Pibid. The movie is available at: https://schoolingtheworld.org/film/. Last access: Sept. 1, 2019.
} 
arena, the control has been exercised mainly through the propagation of methodological orthodoxy and through the publication and distribution of related instructional materials" (KUMARAVADIVELU, 2014, p. 15). Thus, power structures are strengthened and maintained, which tend to be perpetuated in teacher education. In turn, we agree with the author that "critical consciousness and the will to act can be achieved through education” (KUMARAVADIVELU, 2014, p. 11). This critical aspect of education can be noticed in the pre-service teachers' excerpts below:

Mauro: the signs of the film were the things that interested me the most, and I think it is worth mentioning some of them that made me realize later [...], such as the fact that the weapons used to fight the invader were in the museum, the dozens of tips that the residents of Bacurau gave to outsiders to have them visiting the museum, people joining the school to protect themselves, the relationships and how they happened within the community, not only more horizontally but more democratically (in the strong sense of the term, I mean: of government of the people, as opposed to our model of government of having representatives of the people). The whole film, for me, is rich in the nuances, which are clues for very deep discussions about society, politics, culture, sexuality etc. etc. etc.

Samoa: the film is deeply related to the discussions we are having during Pibid, because it also deals with education and its role in society as an essential factor towards change. The debate helped us to understand mainly these questions, of how education was present in the film; the teacher emphasized the importance of the school in the community, how it worked to preserve the city when the population took refuge in it to defend themselves from foreigners. This shows how education will always be the best refuge and the best weapon against those who seek to decimate us.

We consider the emphasis of such statements to be relevant since, as Kumaravadivelu (2014) argues, there is a lower status attributed to nonnative English teachers, who, according to the author, have their role as a subordinate intellectual. For the author, the solution to the unequal power relations in this field, "cannot come from the dominating power; it has to come from the subalterns themselves. It can come, asserts Gramsci, only 
when the subalterns achieve critical consciousness and the collective will to act" (p. 11). As the film portrays, there is a total disregard for the other, for the local knowledge and culture, while ignoring the knowledge, history, and culture of the people portrayed in the film, which, through the collectivity and in connection with education, are able to overcome the enemy who wants to wipe them off the map.

\section{Final words}

The proposals for the Pibid English project were materialized throughout our work, starting with the understanding that teacher education takes place in multiple spaces, in different paths and in a decolonial way. That is, it is important to understand that preparing prospective teachers to go beyond the content that only qualifies, to deal with the uncertainties and insecurities that arise throughout their lives as English teachers and to understand that teacher education activities outside the school environment, and by means of which the local knowledge and contexts are the core of the problem present in such education, should be regarded as a truly important matter.

Among the multiple paths we took, one of them proved to be interesting to achieve our goal, namely, watching films, followed by debates, which involved our going to the movies with the entire group of pre-service teachers, both scholarship holders and volunteers, and the supervisors. The results, as we could observe, were revealed in the expansion of the educational spaces and in the reflections provided by these moments, which we believe will contribute for the future English teachers to understand their teaching role as going beyond the linguistic code and including questions about our being in the world.

Based on the discussion above, we expected to contribute to the ideas of decoloniality, even though we understand, as Kumaravadivelu (2014, p. 17) points out, that "these actionable plans are complex and long-term, but if taken seriously, they have the potential to help the subaltern community move forward."

On account of that, we continue, with the hope that we will keep moving forward in the process of educating, by promoting a reconstitution of values and ways of being... 


\section{Acknowledgements}

We would like to thank Capes for the teacher education grant received as area coordinators, which allowed us to develop the work and research presented in this article.

\section{Autors' contributions}

Sections 1, 2, and 4 were written collaboratively by the two authors. Ana Karina Nascimento authored section 3 and Ana Lúcia Fonseca authored section 5 individually.

\section{References}

BRASIL. Ministério da Educação. Portaria Normativa no 38, de 12 de dezembro de 2007. Dispõe sobre o Programa de Bolsa Institucional de Iniciação à Docência - PIBID. Disponível em: http://portal.mec.gov.br/arquivos/pdf/portaria_pibid. pdf. Acesso em: 12 jan. 2016.

GROSFOGUEL, R. Para descolonizar os estudos de economia política e os estudos pós-coloniais: transmodernidade, pensamento de fronteira e colonialidade global. In: SANTOS, B. S.; MENESES, M. P. (org.). Epistemologias do Sul. São Paulo: Cortez, 2010. p. 455-491. DOI: https://doi.org/10.12957/periferia.2009.3428

JUCÁ, L. Responsabilidades sociais da linguística aplicada na formação de professores de língua inglesa no contexto brasileiro: traçando novos rumos. In: JORDÃO, C. M. (org.). A Linguistica Aplicada no Brasil: rumos e passagens. Campinas, SP: Pontes Editores, 2016. p. 233-265.

KUMARAVADIVELU, B. The Decolonial Option in English Teaching: Can the Subaltern Act? Tesol Quarterly, [S.l.], v. 50, n. 1, p. 66-85, 2014. DOI: https://doi. org/10.1002/tesq.202

MALDONADO-TORRES, N. On the Coloniality of Being: Contributions to the Development of Aconcept. Cultural Studies, [S.l.], v. 21, n. 2-3, p. 240-270, March/ May 2007. DOI: https://doi.org/10.1080/09502380601162548

MENEZES DE SOUZA, L. M. T. O professor de inglês e os letramentos no século XXI: métodos ou ética? In: JORDÃO, C. M.; MARTINEZ, J. Z.; HALU, R. C. (org.). Formação desformatada: práticas com professores de língua inglesa. Campinas, SP: Pontes Editores, 2011. p. 279-303. (Coleção Novas Perspectivas em Linguística Aplicada, 15). 
MIGNOLO, W. Local Histories/Global Designs: Coloniality, Subaltern Knowledges, and Border Thinking. Princeton, NJ: Princeton University Press, 2012. DOI: https://doi.org/10.1515/9781400845064

MOITA LOPES, L. P. Por uma Linguística Aplicada indisciplinar. São Paulo: Parábola Editorial, 2006.

PARDO, F. S. Decolonialidade e ensino de línguas: perspectivas e desafios para a construção do conhecimento corporificado. Revista Letras Raras, Campina Grande, v. 8, n. 3, p. Port. 200-221 / Eng. 198-218, set. 2019. DOI: https://doi. org/10.35572/rlr.v8i3.1422

PESSOA, R. R.; HOELZLE, M. J. Ensino de línguas como palco de política linguística: mobilização de repertórios sobre gênero. Trabalhos de Linguística Aplicada, Campinas, v. 56, n. 3, p. 781-800, set./dez. 2017. DOI: https://doi.org/10.1590 /010318138649840291441

SOUSA SANTOS, B. Para além do pensamento abissal. Novos estudos-CEBRAP, São Paulo, n. 79, p. 71-94, nov. 2007. DOI: https://doi.org/10.1590/S010133002007000300004

Data de recebimento: 12/09/2020. Data de aprovação: 16/09/2020. 